IRA-International Journal of Management \& Social Sciences

ISSN 2455-2267; Vol.06, Issue 02 (2017)

Pg. no. 286-291

Institute of Research Advances

https://research-advances.org/index.php/RAJMSS

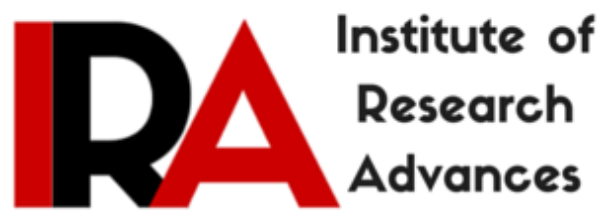

\title{
A Non -Parametric Test for Stress of Bank Employees (Comparison of Public vs. Private Sector Banks)
}

\author{
Dr.Sandeep Nath Modi ${ }^{1}$, Dr. Samir Kumar ${ }^{2}$ \\ ${ }^{1}$ Manager, Syndicate Bank \& Faculty (on deputation) at National Institute of Financial \\ Management, Ministry of Finance, Government of India, Faridabad, Haryana-121001 (India). \\ ${ }^{2}$ Sr.Manager, Syndicate Bank \& Faculty (on deputation) at National Institute of Financial \\ Management, Ministry of Finance, Government of India, Faridabad, Haryana-121001 (India).
}

Type of Review: Peer Reviewed.

DOI: http://dx.doi.org/10.21013/jmss.v6.n2.p12

\section{How to cite this paper:}

Modi, S., \& Kumar, S. (2017). A Non -Parametric Test for Stress of Bank Employees (Comparison of Public vs. Private Sector Banks). IRA-International Journal of Management \& Social Sciences (ISSN 2455-2267), 6(2), 286-291. doi:http://dx.doi.org/10.21013/jmss.v6.n2.p12

(C) Institute of Research Advances

(c) EY-NC

This work is licensed under a Creative Commons Attribution-Non Commercial 4.0 International License subject to proper citation to the publication source of the work.

Disclaimer: The scholarly papers as reviewed and published by the Institute of Research Advances (IRA) are the views and opinions of their respective authors and are not the views or opinions of the IRA. The IRA disclaims of any harm or loss caused due to the published content to any party. 


\begin{abstract}
Employee performance is the key driving force for organizational success and at the same time pressure become the part \& parcel in organizations for keeping employees motivated to win the competitive race. But undue pressure can causes stress which reduces performance. Stress is ubiquitous phenomenon and a straining condition that has a negative impact on an individual's physical, physiological, personal and family life. Quality of Work Life is an intricate and comprehensive concept implying a concern for the members of an organization irrespective of the level they belong to. It includes job factors such as health and well-being, working conditions, attitude level etc. the success of any organisation especially in banking sector depends on quality of work life of employees because management of people and management of risk are the two important challenges faced by banks today. So the present study aims to make a comparative study of the quality of work life among public and private sector bank employees in Haryana.
\end{abstract}

Key Words: Quality of Work Life, Private Sector, Public Sector, Working Condition, Health and Wellbeing, Stress

JEL Classification: I18, J28, G21, I38

\title{
1. Backdrop
}

The word "stress" first used in physics and then it became the part of psychology. Hob full (1989) defines this term as "when people starts to oppose external environment or forces". According to M. Keinan, stress is the interaction between the person and the environment. Due to massive amount Job stress has become a major challenge for the organizations d. So now a day's employee's behaviour is significantly affected by the job stress. Due to their major role in running the organizations effectively and successfully, it is clearly understood that employees are the most important assets of any organizations and they cannot be treated like machines. It is clear that employees who works in stress free environment are more productive and proves to be most valued assets for an organization but those organizations which are not committed with their employees stress, employee absenteeism is more, low turnover, work ineffectiveness and usually legal financial damages persists.In service sector undertakings, banks play a key position in the economic growth of a country. A bank is an organisation whose debts are generally accepted in completion of other people's debt to each other. The institution of banks plays an exceptional position in the economic structure of any country and it has its close association with growth efforts. They function as catalysts of entrepreneurial activity, an important condition for all round economic growth. By offering attractive interest on the savings of the people deposited with them, banks support the habit of thrift and savings among the people. By accepting savings of people, banks provide safety and security to the surplus money of the depositors; they help trade and commerce, industry and agriculture by meeting their financial requirements. Through the process of creation of money, banks attain control over the supply of money; they influence the economic activities, employment, income and general price level in the country. Since banking sector is a service industry, management of people and management of risk are the important challenges facing by them. Without well-organized and skilful manpower, proper risk management may not be possible in an effective manner. As competition is the driving force of banking sector, it is necessary to adopt proper integration of both human resource management strategies with business strategies. For this purpose, it is necessary to maintain work life balances of human experiences in work environment.

\section{Objectives of the Study}

The main objective of the study is to compare the Quality of Work life among Public and Private sector bank employees. For achieving the stated objectives the variables of health and well-being, attitude and work life balances are taken for study. 


\section{Database and Methodology}

The present study is analytical and explorative in nature and it is based on both primary and secondary data. The primary data required for the study has been collected from the samples employees of public and private sector banks. A structured questionnaire was used for this purpose. The secondary data is required for the study has been obtained from various books and articles relating to the topic.

\section{Sample Design}

A simple random sampling method was adopted for the respondent selection and 526 questionnaires were distributed in total. 262 from public and 264 from private sector were collected as sample. For this SBI and PNB were selected as public sector banks and Axis Bank and HDFC Bank were selected from private sector banks.

\section{Data Analysis}

\subsection{Descriptive analysis of banks with health and well-being}

Table 1.1 indicates that the mean ratings of the elements of the variable "health and well-being". On the basis of the sector wise analysis it found that while analysing the statements like the continuous hard work of job create more physical and psychological problems, direct and indirect effect of computerization affects workers health and well-being, this job doesn't offer maternity benefits and crushes and there is a lack of favourable welfare facilities there is no significant difference among the employees of both public and private sector banks because the $p$ value is greater than .05 . At the same time while considering the statements like physical illness and psychological disorders occurs while dealing with customers and this job doesn't offer protection against disease and injury within the organization, the mean ratings of Private sector bank is higher than that of public. It also inferred that since the $\mathrm{p}$ value is less than 0.05 , there is a significant difference among them.

\section{Table 5.1}

Descriptive Analysis of banks with health and well-being

\begin{tabular}{|c|c|c|c|c|c|c|c|}
\hline $\begin{array}{l}\text { Health and well } \\
\text { being }\end{array}$ & Bank & $\mathbf{N}$ & $\begin{array}{l}\text { Mean } \\
\text { Rank }\end{array}$ & $\begin{array}{l}\text { Sum of } \\
\text { Ranks }\end{array}$ & $\begin{array}{c}\text { CVTS } \\
\text { (Mann- } \\
\text { Whitney } \\
\text { U Test) }\end{array}$ & $P$ value & Result \\
\hline \multirow{3}{*}{$\begin{array}{l}\text { The continuous } \\
\text { hard work of this } \\
\text { job creates more } \\
\text { physical and } \\
\text { psychological } \\
\text { problems }\end{array}$} & Public & 262 & 267.97 & 70209.00 & \multirow[b]{3}{*}{.779} & \multirow[b]{3}{*}{.436} & \\
\hline & Private & 264 & 259.06 & 68392.00 & & & \\
\hline & Total & 526 & & & & & $\begin{array}{c}\text { Not } \\
\text { significant }\end{array}$ \\
\hline \multirow{3}{*}{$\begin{array}{l}\text { Direct and indirect } \\
\text { effect of } \\
\text { computerization } \\
\text { affects workers } \\
\text { health and well- } \\
\text { being }\end{array}$} & Public & 262 & 264.06 & 69183.50 & \multirow[b]{3}{*}{0.089} & \multirow[b]{3}{*}{0.929} & \\
\hline & Private & 264 & 262.95 & 69417.50 & & & \\
\hline & Total & 526 & & & & & $\begin{array}{c}\text { Not } \\
\text { significant }\end{array}$ \\
\hline \multirow{3}{*}{$\begin{array}{l}\text { Physical illness and } \\
\text { psychological } \\
\text { disorders occurs } \\
\text { while dealing with } \\
\text { customers }\end{array}$} & Public & 262 & 223.40 & 58532.00 & \multirow[b]{3}{*}{-6.954} & \multirow[b]{3}{*}{0.000} & \\
\hline & Private & 264 & 303.29 & 80069.00 & & & \\
\hline & Total & 526 & & & & & Significant \\
\hline \multirow{3}{*}{$\begin{array}{l}\text { This job doesn't } \\
\text { offer facilities like } \\
\text { maternity benefits, } \\
\text { crushes etc. }\end{array}$} & Public & 262 & 268.49 & 70345.00 & & & \\
\hline & Private & 264 & 258.55 & 68256.00 & & & \\
\hline & Total & & & & -0.839 & 0.402 & $\begin{array}{c}\text { Not } \\
\text { Significant }\end{array}$ \\
\hline
\end{tabular}




\begin{tabular}{|c|c|c|c|c|c|c|c|}
\hline \multirow{3}{*}{$\begin{array}{l}\text { This job doesn't } \\
\text { offer protection } \\
\text { against disease and } \\
\text { injury within the } \\
\text { organization }\end{array}$} & Public & 262 & 215.20 & 56382.00 & & & \\
\hline & Private & 264 & 311.44 & 82219.00 & & & \\
\hline & Total & 526 & & & -7.800 & 0.000 & Significant \\
\hline \multirow{3}{*}{$\begin{array}{l}\text { This job doesn't } \\
\text { offer favourable } \\
\text { welfare facilities }\end{array}$} & Public & 262 & 253.32 & 66369.50 & & & \\
\hline & Private & 264 & 273.60 & 72231.50 & & & \\
\hline & Total & 526 & & & -1.739 & 0.082 & $\begin{array}{c}\text { Not } \\
\text { Significant }\end{array}$ \\
\hline
\end{tabular}

(Source: Primary Data)

\subsection{Descriptive Analysis of Bank with attitude level of respondents}

Table 1.2 depicts that while analysing the statements like 'this job lets me to use my skills and abilities in an effective manner', 'this job give chance for personal development', and 'this job makes me interesting, energetic and enthusiastic', statistically there is no significant differences among the opinions of respondents with reference to sector. But by taking other statements such as 'this job creates leadership qualities and team spirit' and 'this job provides opportunity for providing innovative ideas', since the $\mathrm{P}$ value is less than 0.05 statistically there is significant differences among the opinion of sector wise respondents. It is also inferred that the opportunity of the creation of leadership qualities, team spirit and innovative ideas is more in the case of Public sector.

Table 5.2

Descriptive Analysis of banks with attitude level of respondents

\begin{tabular}{|c|c|c|c|c|c|c|c|}
\hline Attitude & Bank & $\mathbf{N}$ & $\begin{array}{l}\text { Mean } \\
\text { Rank }\end{array}$ & $\begin{array}{l}\text { Sum of } \\
\text { Ranks }\end{array}$ & $\begin{array}{l}\text { CVTS } \\
\text { (Mann- } \\
\text { Whitney } \\
\text { U Test) } \\
\end{array}$ & P value & Result \\
\hline \multirow{4}{*}{$\begin{array}{l}\text { This job lets me to } \\
\text { use my skills and } \\
\text { abilities in an } \\
\text { effective manner }\end{array}$} & Public & 262 & 265.61 & 69590.00 & \multirow[b]{4}{*}{-.351} & \multirow[b]{4}{*}{.726} & \\
\hline & Private & 264 & 261.41 & 69011.00 & & & \\
\hline & & & & & & & \\
\hline & Total & 526 & & & & & $\begin{array}{c}\text { Not } \\
\text { significant }\end{array}$ \\
\hline \multirow{3}{*}{$\begin{array}{l}\text { This job creates } \\
\text { leadership qualities } \\
\text { and team spirit }\end{array}$} & Public & 262 & 282.98 & 74140.50 & \multirow[b]{3}{*}{-3.498} & \multirow[b]{3}{*}{0.000} & \\
\hline & Private & 264 & 244.17 & 64460.50 & & & \\
\hline & Total & 526 & & & & & Significant \\
\hline \multirow{3}{*}{$\begin{array}{l}\text { This job provides } \\
\text { opportunity for } \\
\text { providing } \\
\text { innovative ideas }\end{array}$} & Public & 262 & 299.64 & 78505.00 & \multirow[b]{3}{*}{-7.276} & \multirow[b]{3}{*}{0.000} & \\
\hline & Private & 264 & 227.64 & 60096.00 & & & \\
\hline & Total & 526 & & & & & Significant \\
\hline \multirow{3}{*}{$\begin{array}{c}\text { This job give } \\
\text { chance for personal } \\
\text { development }\end{array}$} & Public & 262 & 260.66 & 68293.50 & & & \\
\hline & Private & 264 & 266.32 & 70307.50 & & & \\
\hline & Total & & & & -0.459 & 0.646 & $\begin{array}{c}\text { Not } \\
\text { Significant }\end{array}$ \\
\hline \multirow{3}{*}{$\begin{array}{l}\text { This job makes me } \\
\text { interesting, } \\
\text { energetic and } \\
\text { enthusiastic }\end{array}$} & Public & 262 & 253.66 & 66458.50 & & & \\
\hline & Private & 264 & 273.27 & 72142.50 & & & \\
\hline & & & & & & & Not \\
\hline
\end{tabular}




\begin{tabular}{|l|l|l|l|l|l|l|l|}
\hline & Total & 526 & & & -1.646 & 0.100 & Significant \\
\hline
\end{tabular}

(Source: Primary Data)

\subsection{Descriptive Analysis of Bank with work life balances}

From the analysis of 1.3 reveals that while considering the factors like working hours of the job and balance among career, family life and leisure activities the mean score of respondents of public is higher than that of private sector bank employees. CVTS (Mann-Whitney U Test) analysis shows that there is significant difference among the opinions of respondents because the $\mathrm{p}$ value is less than .05 . But by taking the factor of work life atmosphere of job, the mean rating of respondents at public is higher than that of respondents at Private sector. It is inferred that since the $\mathrm{p}$ values is 0.212 (more than .05) statistically there is no significant difference in opinions of respondents. At that time by considering the factor of distance between work place and home the mean ratings of the respondents at Private sector banks is of higher position. It also reveals that statistically there is significant difference in opinion because the $\mathrm{p}$ value is less than .05 . While analysing the factor opportunities for spending with family, the mean of the respondents of private sector banks is of the highest position. But the Mann Whitney $U$ test reveals that since the p value is less than .05 statistically there is no significant difference among the opinions of respondents.

Table 5.3

Descriptive Analysis of banks with work life balances

\begin{tabular}{|c|c|c|c|c|c|c|c|}
\hline $\begin{array}{l}\text { Work Life } \\
\text { Balances }\end{array}$ & Bank & $\mathbf{N}$ & $\begin{array}{l}\text { Mean } \\
\text { Rank }\end{array}$ & $\begin{array}{l}\text { Sum of } \\
\text { Ranks }\end{array}$ & $\begin{array}{l}\text { CVTS } \\
\text { (Mann- } \\
\text { Whitney } \\
\text { U Test) } \\
\end{array}$ & $P$ value & Result \\
\hline \multirow{3}{*}{$\begin{array}{l}\text { Working hours of } \\
\text { the job }\end{array}$} & Public & 262 & 284.34 & 74496.00 & \multirow[b]{3}{*}{-3.338} & \multirow[b]{3}{*}{.001} & \\
\hline & Private & 264 & 242.82 & 64105.00 & & & \\
\hline & Total & 526 & & & & & Significant \\
\hline \multirow{3}{*}{$\begin{array}{c}\text { Work life } \\
\text { atmosphere of the } \\
\text { job }\end{array}$} & Public & 262 & 270.58 & 70892.00 & \multirow[b]{3}{*}{-1.248} & \multirow[b]{3}{*}{0.212} & \\
\hline & Private & 264 & 256.47 & 67709.00 & & & \\
\hline & Total & 526 & & & & & $\begin{array}{c}\text { Not } \\
\text { Significant }\end{array}$ \\
\hline \multirow{3}{*}{$\begin{array}{c}\text { Distance between } \\
\text { work place and } \\
\text { home }\end{array}$} & Public & 262 & 232.18 & 60832.00 & \multirow[b]{3}{*}{-5.127} & \multirow[b]{3}{*}{0.000} & \\
\hline & Private & 264 & 294.58 & 77769.00 & & & \\
\hline & Total & 526 & & & & & Significant \\
\hline \multirow{3}{*}{$\begin{array}{l}\text { Opportunities for } \\
\text { spending with } \\
\text { family }\end{array}$} & Public & 262 & 257.10 & 67361.00 & & & \\
\hline & Private & 264 & 269.85 & 71240.00 & & & \\
\hline & Total & & & & -1.070 & 0.285 & $\begin{array}{c}\text { Not } \\
\text { Significant }\end{array}$ \\
\hline \multirow{3}{*}{$\begin{array}{l}\text { Balance among } \\
\text { career, family life } \\
\text { and leisure } \\
\text { activities }\end{array}$} & Public & 262 & 278.05 & 72848.00 & & & \\
\hline & Private & 264 & 249.06 & 65753.00 & & & \\
\hline & Total & 526 & & & -2.320 & 0.020 & Significant \\
\hline
\end{tabular}

(Source: Primary Data)

\section{Findings of the Study}

While considering the factor 'health and well-being' in sector wise it shows that majority of the respondents (both in public and private sector banks) agree that the continuous hard work of the job 
creates more physical and psychological problems, direct and indirect effect pf computerization affects worker's health and well-being, banking sector doesn't offer sufficient facilities of crushes and other welfare activities. At the same time employees at private sector banks argued that psychological problems are more only when dealing with customers and there is no protection against disease and injury within the organization. It shows an increasing growth of private sector banks. While analysing attitudinal factors in sector wise it is found that the opportunity for the creation of leadership qualities, team spirit and use of innovative ideas is more in the case of public sector.

Working hours of the job, work life atmosphere, balance among career growth is comfortable in public sector and at the same time in the case of private sector opportunities for spending time with family are comfortable.

\section{Conclusion}

No organization can run successfully unless the human resources are managed well. As the banking sector is highly competitive, it is necessary to maintain a better workforce. The labour turnover in the private banking industry is high mainly because of the improper work life balances. The effects of continuous hard work of the employees can be overcome by adopting 'Career Option Scheme', in which employees can apply for a flexible choice such as job sharing, job rotation etc.

\section{References}

Department of Financial Services, Ministry of Finance, Government of India.

Marelize Goergens, Jody Zall Kusek (2009), Monitoring and Evaluation System That Work: A Resource for Development Practitioners, The World Bank, Washington DC, ISBN - 978-0-82138186-1.

P. Srirenganayaki, A. Jayakumar (2016), Quality of Work Life (QWL) of Women Employees in Banking Sector: QWL of Women Bank Employees,LAP LAMBERT Academic Publishing, ISBN 978-3659964985.

RBI Bulletin.

www.abbinavjournal.com. 